\title{
KOMPETENCJE KULTUROWE I INTELIGENCJA KULTUROWA W PIELĘGNIARSTWIE
}

\section{CULTURAL COMPETENCES AND CULTURAL INTELLIGENCE IN NURSING}

\author{
Anna Majda, Joanna Zalewska-Puchała \\ Wydział Nauk o Zdrowiu \\ Uniwersytet Jagielloński - Collegium Medicum
}

DOI: https://doi.org/10.20883/pielpol.2018.24

\section{STRESZCZENIE}

Wstęp. Współcześnie kompetencje kulturowe i inteligencja kulturowa są niezbędne w kontekście międzynarodowych interakcji naukowych, edukacyjnych, współpracy transgranicznej, zwiększających się możliwości i zmieniających się form zatrudnienia na rynku pracy, uchodźctwa, zarządzania różnorodnością w międzynarodowych zespołach projektowych, misji wojennych czy wreszcie turystyki medycznej. Nie bez znaczenia są zachodzące $w$ świecie zmiany ekonomiczne, polityczne, społeczne, technologiczne, generacyjne (pokoleniowe). W Polsce pojawia się coraz więcej cudzoziemców, którzy stają się klientami polskiej ochrony zdrowia.

Cel. Przedstawienie komponentów kompetencji kulturowych i inteligencji kulturowej osób udzielających świadczeń zdrowotnych, głównie pielęgniarek, oraz ich roli. Artykuł stanowi wynik krytycznej analizy źródeł wtórnych w literaturze przedmiotu, tj. publikacji książkowych i artykułowych, oraz doświadczeń własnych autorek.

Wyniki. Kompetencje kulturowe to świadomość (wrażliwość) własnego systemu wartości i wynikających z tego faktu ograniczeń, punktu widzenia pacjenta, istnienia różnych perspektyw, hierarchii wartości, norm i wzorów zachowań; wiedza - dostarczająca informacji specyficznych kulturowo; umiejętności - obejmujące wielokulturowe strategie interwencyjne.

Inteligencja kulturowa jest specyficzną formą inteligencji, skoncentrowanej na zdolności jednostki do rozumienia, poprawnego wnioskowania, funkcjonowania, zarządzania, radzenia sobie w sytuacjach charakterystycznych dla zróżnicowania kulturowego. Składa się z czterech komponent: poznawczej, metapoznawczej, motywacyjnej, behawioralnej.

Wnioski. Posiadanie kompetencji kulturowych w pielęgniarstwie jest konieczne, pozwala na zmniejszanie potencjalnych negatywnych skutków różnic kulturowych, dotyczących artefaktów, wartości, norm, zachowań. Rozwijanie i doskonalenie inteligencji kulturowej w pielęgniarstwie jest niezbędnym procesem rozciągniętym w czasie, trudnym, ale mogącym przynosić satysfakcję, ułatwiającym przełamywanie stereotypów, które utrudniają relacje między przedstawicielami różnych kultur.

SŁOWA KLUCZOWE: inteligencja kulturowa, kompetencje kulturowe, pielęgniarstwo.

\begin{abstract}
Introduction. Contemporary cultural competences and cultural intelligence are essential in the context of international interactions in science, education, cross-border cooperation, increasing opportunities and changing employment patterns in the labor market, refugee management, diversity management in international project teams, war missions, and medical tourism. Noteworthy are the economic, political, social, technological, generational changes in the world. In Poland, there are more and more foreigners who become clients of Polish health care.

Aim. Presentation of the components of cultural competences and cultural intelligence of health care providers, mainly nurses, and their role. This article is the result of a critical analysis of secondary sources in the literature of the subject, i.e. book and article publications, and the author's own experiences.

Results. Cultural competence is the awareness of one's own system of values and the resulting limitations, the patient's perspective, the existence of different perspectives, the hierarchy of values, norms and patterns of behavior; knowledge - providing information that is culturally specific; skills - covering multicultural intervention strategies.

Cultural intelligence is a specific form of intelligence, focused on the individual's ability to understand, correctly reason, function, manage, deal with situations that are characteristic of cultural diversity. It consists of four components: cognitive, metaphorical, motivational, and behavioral.

Conclusions. Having cultural competence in nursing is necessary to reduce the potential negative effects of cultural differences in artefacts, values, norms, behaviors. Developing and improving cultural intelligence in nursing is an indispensable, time-stretching, difficult but rewarding process that facilitates breaking stereotypes that hinder relations between representatives of different cultures.
\end{abstract}

KEYWORDS: cultural intelligence, cultural competence, nursing. 


\section{Wprowadzenie}

Współcześnie kompetencje kulturowe i inteligencja kulturowa są niezbędne w kontekście międzynarodowych interakcji naukowych, edukacyjnych, współpracy transgranicznej, zwiększających się możliwości i zmieniających się form zatrudnienia na rynku pracy, uchodźctwa, zarządzania różnorodnością w międzynarodowych zespołach projektowych, misji wojennych czy wreszcie turystyki medycznej. Nie bez znaczenia są zachodzące w świecie zmiany ekonomiczne, polityczne, społeczne, technologiczne, generacyjne (pokoleniowe) [1-5].

W Polsce pojawia się coraz więcej cudzoziemców, którzy stają się klientami polskiej ochrony zdrowia. $Z$ badań wynika, że personel medyczny, ze względu na barierę językową i brak kompetencji kulturowych, napotyka na trudności o charakterze kulturowym w opiece nad obcokrajowcami. Wynikają one z niskiego poziomu kompetencji kulturowych zarówno klientów zagranicznych, jak i udzielających świadczeń zdrowotnych [6].

Przed zespołami interdyscyplinarnymi podmiotów leczniczych, w tym pielęgniarek sprawujących funkcję liderów tych zespołów czy zarządzających opieką nad pacjentami pochodzącymi z różnych kręgów kulturowych, pojawia się nowe wyzwanie - przygotowanie (treściowe, metodologiczne) do zdobywania kompetencji kulturowych i rozwijania inteligencji kulturowej. Konieczne jest odpowiednie kształcenie pielęgniarek zarówno przed-, jak i podyplomowe, profesjonalnie przygotowujące do udzielania świadczeń zdrowotnych dostosowanych kulturowo do każdego pacjenta, niezależnie od jego narodowości, pochodzenia społecznego, kulturowego, przynależności do grupy etnicznej czy religijnej. Kształtowanie kompetencji kulturowych jest potrzebne do poprawy dialogu międzykulturowego, obejmującego umiejętności językowe i społeczne, otwartość i wrażliwość na inne kultury oraz świadomość własnego dziedzictwa kulturowego oraz ich wpływu na komunikowanie międzykulturowe. Jest niezbędne do zapewnienia wysokiej jakości opieki i zadowolenia pacjentów pochodzących z odmiennych kręgów kulturowych, unikania nieporozumień czy błędnego diagnozowania, leczenia, pielęgnowania, edukowania, wspierania, komunikowania się [7-14]. Rolę kompetencji międzykulturowych we współczesnej medycynie podkreślają też autorzy spoza branży $[4,15,16]$. O kompetencjach kulturowych piszą pracownicy naukowo-dydaktyczni uczelni kształcących kadry medyczne, głównie pielęgniarki o dużym dorobku naukowym w zakresie ochrony zdrowia, bogatym doświadczeniu zawodowym, dydaktycznym, kulturowym - zdobytym podczas różnego rodzaju form kształcenia podyplomowego w obszarze kultury, religii, antropologii. Często też wespół z osobami wywodzącymi się ze środowisk reprezentujących różne religie i kultury czy z pracownikami naukowymi reprezentującymi pokrewne dziedziny, np. psychologię, pedagogikę, socjologię, religioznawstwo, filozofię, teologię, medycynę. Pielęgniarki, w tym autorki artykułu, dzielą się swym doświadczeniem w zdobywaniu kompetencji kulturowych przez studentów pielęgniarstwa, przedstawiając nowoczesne metody i formy pracy w edukacji międzykulturowej pielęgniarek w czasie konferencji krajowych i międzynarodowych [17-28], należą do międzynarodowych organizacji, np. European Transcultural Nursing Association (ETNA). Wśród pracowników ochrony zdrowia prowadzą badania na temat oceny kompetencji kulturowych. $Z$ badań tych wynika, że pielęgniarki są grupą zawodową, którą cechuje najwyższa zdolność do rozumienia uczuć osób odmiennych kulturowo [10]. Zaś wśród studentów pielęgniarstwa prowadzą badania na temat postaw wobec osób odmiennych kulturowo [2930], co wydaje się być ważnym problemem, gdyż stanowi o afektywnej składowej kompetencji kulturowych. Należy zauważyć, że są autorzy czy organizacje, np. Helsińska Fundacja Praw Człowieka, którzy zauważają dobre praktyki na rzecz poprawy jakości usług medycznych świadczonych migrantom - środowisko medyczne wydaje np. publikacje poświęcone zagadnieniom perspektywy międzykulturowej w medycynie [31]. Warto zauważyć też, że są autorzy, którzy kontestują potrzebę zdobywania kompetencji kulturowych przez studentów pielęgniarstwa [32], gdy tymczasem, jak wspomniano powyżej, jest to temat ważny i często poruszany w literaturze rodzimej i zagranicznej z zakresu pielęgniarstwa i zdrowia publicznego [33, 38]. Poza tym kształtowanie kompetencji kulturowych jest istotnym zadaniem rozwojowym dla każdego współczesnego człowieka, w przestrzeni którego znajdują się cudzoziemcy.

\section{Cel pracy}

Przedstawienie komponentów kompetencji kulturowych i inteligencji kulturowej osób udzielających świadczeń zdrowotnych, głównie pielęgniarek, oraz ich roli. Artykuł stanowi wynik krytycznej analizy źródeł wtórnych w literaturze przedmiotu, tj. publikacji książkowych i artykułowych, oraz doświadczeń własnych autorek.

\section{Omówienie}

\section{Kompetencje kulturowe}

W literaturze naukowej można znaleźć wiele definicji terminu „kompetencje”, mogą być one na poziomie indywidualnym i organizacyjnym. W najprostszym ujęciu to dyspozycje w zakresie wiedzy, umiejętności i postaw, które pozwalają realizować zadania zawodowe na odpowiednim poziomie [39]. 
Kompetencje kulturowe czasami zamiennie określane jako kompetencje międzykulturowe [4, 11, 40], stanowią „wypadkową czterech wymiarów: wiedzy o odmienności kulturowej, reakcji na sytuacje związane z obecnością odmienności kulturowej, pozycji na kontinuum etnocentryzm-relatywizm oraz samooceny postaw wobec odmienności kulturowej" [40, s. 59]. Według innych autorów kompetencje kulturowe to świadomość (wrażliwość) własnego systemu wartości i wynikających z tego faktu ograniczeń, punktu widzenia pacjenta, istnienia różnych perspektyw, hierarchii wartości, norm i wzorów zachowań; wiedza - dostarczająca informacji specyficznych kulturowo; umiejętności - obejmujące wielokulturowe strategie interwencyjne [41].

Campinha-Bacote definiuje kompetencje kulturowe jako proces, w którym pielęgniarka ciągle stara się i dąży do skutecznej pracy z pacjentem, uwzględniając kontekst kulturowy pacjenta, jego rodziny i społeczności, w której żyje, rozumiejąc kulturowy kontekst wielu przekazów werbalnych i pozawerbalnych. Kompetencje obejmują kulturową świadomość (wrażliwość), wiedzę, umiejętności i doświadczenie kulturowych spotkań. Metaforą jest wulkan, z którego krateru po gwałtownym wybuchu/gwałtownej erupcji wydobywa się spokojnie lawa, symbolizując proces budowania kompetencji kulturowych. Jeśli „eksploduje” chęć zaangażowania się kulturowego, to rozpoczyna się proces pokornego, powolnego stawania się kulturowo fachowym profesjonalistą. Skuteczne nabywanie kompetencji kulturowych jest wynikiem „chęci” i własnych aspiracji, a nie konieczności i desperacji [42].

Posiadanie kompetencji kulturowych to wg autorek artykułu umiejętności komunikowania międzykulturowego, zrozumienia kulturowego wymiaru postrzegania i przekonań dotyczących siebie i innych. Bowiem kultura, w której wzrastamy, wpływa na nasze zachowania, wyznawane wartości i normy, a te w kontakcie międzykulturowym, w sytuacji konfrontacji z innością mogą być podważane, co może być źródłem frustracji, zniechęcenia do podtrzymywania kontaktu, a także utrzymywania stereotypów i uprzedzeń.

Wśród pielęgniarek pojawia się konieczność zrozumienia, że różnice kulturowe występują w stosunku do zdrowia, w zachowaniach zdrowotnych, w sposobach reagowania na narodziny, chorobę, śmierć. Przedstawiciele różnych religii i kręgów kulturowych mają często te same potrzeby podczas choroby czy pobytu w szpitalu (np. jedzenia, czystości, wydalania, okazywania uczuć), tylko sposób ich ekspresji może być różny, często tylko subtelnie różny, niezauważalny dla osoby mało wrażliwej kulturowo. Mogą mieć również różne oczekiwania wobec opieki medycznej: diagnozowania, leczenia, pielęgnowania, edukowania, komunikowania, wsparcia. Różnice kulturowe, znajdujące odzwierciedlenie w od- miennym sposobie komunikowania, podejściu do czasu, przestrzeganiu terminów, rozwiązywaniu problemów, podejmowaniu decyzji, nawiązywaniu i utrzymywaniu relacji, to pułapki, na które pielęgniarki powinny zwracać uwagę. „Zaprogramowanie kulturowe” sprawia, że trudno jest kontrolować każdy gest, mimikę, ton głosu, kiedy trzeba koncentrować się też na treści przekazu.

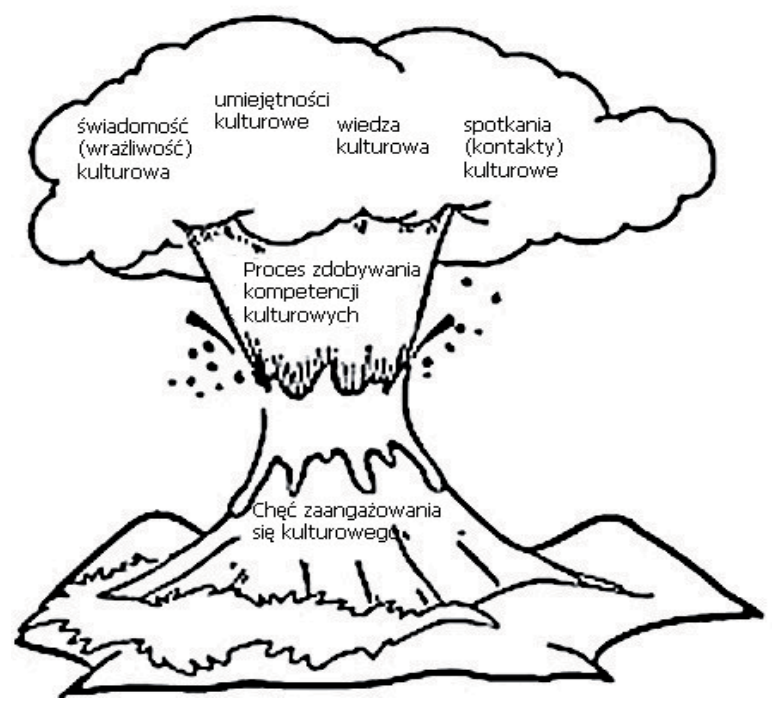

świadomość (wrażliwość kulturowa)/cultural awareness; umiejętności kulturowe/cultural skills; wiedza kulturowa/cultural knowledge; spotkania (kontakty) kulturowe/cultural encounters; proces zdobywania kompetencji kulturowych/the process of cultural competences; proces zaangażowania się kulturowego/cultural desire

Rycina 1. Proces rozwoju kompetencil kulturowych [Campinha-Bacote J. Many Faces: Addressing Diversity in Health Care. The Online Journal of Issues in Nursing. 2003; 8(1), http://www.nursingworld.org] Figure 1. The development process of cultural competences [Campinha-Bacote J. Many Faces: Addressing Diversity in Health Care. The Online Journal of Issues in Nursing. 2003; 8(1), http://www.nursingworld.org]

Autorki artykułu uważają, że wrażliwość kulturowa to bardzo ważny element składowy kompetencji kulturowych [9]. Wrażliwość kulturowa to świadomość różnic międzykulturowych i wyczucie ich w sytuacjach, gdy się ma z nimi do czynienia. To postawa zrozumienia, empatii, otwartości, ciekawości, elastyczności i braku uprzedzeń w relacjach międzykulturowych [35]. Milton Bennett [43] stworzył model rozwoju wrażliwości międzykulturowej, który ma charakter procesu przechodzącego przez dwa etapy, od etnocentryzmu do etnorelatywizmu. Opiera się na założeniu, że w miarę doświadczania różnicy kulturowej przez jednostkę jej kompetencja w stosunkach międzykulturowych rośnie. Opierając się na psychologii poznawczej i konstruktywizmie, Bennett zorganizował swoje obserwacje w sześć stadiów rosnącej wrażliwości na różnice międzykulturowe (zaprzeczenie, obrona, minimalizacja, akceptacja, adaptacja, integracja). Każde stadium wskazuje na szczególną strukturę poznawczą, która wyraża się 
przez pewne rodzaje postaw i zachowań, od radykalnych - odrzucających, do liberalnych - akceptujących różnorodność. Model ten jest swego rodzaju ścieżką indywidualnego rozwoju jednostki, stanowiącą o wzrastającej świadomości kulturowej.

Na złoty standard w kontaktach międzykulturowych zwraca uwagę Gesteland [44], mówiąc, że „w biznesie międzynarodowym oczekuje się, że sprzedawca dostosuje się kulturowo do nabywcy", czyli nauczy się kultury partnera i dostosuje do niej swoje zachowania. Autorki artykułu stoją na stanowisku, że relacja pielęgniarka pacjent z odmiennego kręgu kulturowego powinna dotyczyć dostosowania się kulturowego dwóch stron kontaktu, tzw. gospodarzy i gości - przedstawicieli kultury większościowej i mniejszościowej, bo za dobre/skuteczne porozumienie odpowiedzialne są obie strony relacji. Powinno być to spotkanie „w połowie drogi”, powinny przygotować się do niego obie strony, powinien być to wysiłek obustronny, aby był satysfakcjonujący. W relacji pacjent - pielęgniarka ważnym jest, aby obie strony wzajemne szanowały odmienne wartości, normy i zachowania wynikające z odrębnych doświadczeń kulturowych.

Zapewnienie kompetentnej kulturowo opieki pielęgniarskiej oznacza, że opieka jest zaplanowana w sposób biorący pod uwagę potrzeby jednostki, rodziny i różnych grup w społeczeństwie. W opiece kompetentnej kulturowo należy kierować się zasadą: nie musimy mieć wspólnych z pacjentem „korzeni” kulturowych czy systemu wartości, aby sprawować nad nim kompetentną opiekę, musimy mieć natomiast skuteczne narzędzia w postaci procedur, wiedzy kulturowej oraz chęci pomocy. Kompetencja w zakresie opieki zdrowotnej uwarunkowanej kulturowo to szanowanie odrębności kulturowej pacjenta, to otwartość na jego odmienny system wartości, wyznanie, język, tradycję, historię, to opieranie relacji nie tylko na podobieństwach, ale dostrzeganie także różnic.

Elementami kulturowej kompetencji wg Purnella [45, 46] sa:

- $\quad$ rozwój świadomości (wrażliwości), aby pacjent nie odczuwał nadmiernego wpływu osób z innej kultury;

- demonstracja wiedzy i zrozumienia dla kultury pacjenta, potrzeb związanych ze zdrowiem oraz znaczenia zdrowia oraz choroby dla jego kultury;

- akceptacja i respektowanie różnic kulturowych, aby pacjent i jego rodzina mieli możliwość podejmowania decyzji zgodnie ze swoimi potrzebami i przekonaniami;

- $\quad$ założenie, że przekonania i wartości pacjenta i osoby zapewniającej opiekę są różne;

- odrzucenie postaw typu „inne nie jest dobre”;

- bycie otwartym na inne kultury;
- akceptacja odpowiedzialności za własną edukację w zakresie kompetencji kulturowej (literatura, kursy, konferencje).

Powyższe elementy sugerują, że kulturowa kompetencja to wyzwanie na całe życie. Pielęgniarki, które respektują i umieją rozpoznać różnice kulturowe, są lepiej przygotowane do niesienia pomocy pacjentom. Model kulturowej kompetencji Larry'ego Purnella składa się z czterech poziomów - przechodzenia od nieświadomej niekompetencji (pielęgniarka błędnie interpretuje zachowania innych i nie jest tego świadoma), poprzez świadomą niekompetencję (pielęgniarka wie, że błędnie interpretuje zachowania innych, ale nic z tym nie robi) i świadomą kompetencję (pielęgniarka myśli nieustannie o komunikacji międzykulturowej i stara się zmieniać swoje zachowania, aby osiągnąć większą skuteczność), do nieświadomej kompetencji (pielęgniarka rozwinęła umiejętność komunikowania międzykulturowego w takim stopniu, że nie musi myśleć o tym, jak się zachowuje). Model ten obejmuje:

Rozwój kulturowej samoświadomości: zanim pielęgniarka będzie w stanie zapewnić pacjentowi opiekę kulturowo kompetentną, musi uświadomić sobie, w jaki sposób czynniki kulturowe wpływają na jej życie. Obiektywnie zbadać/ocenić własne praktyki, wierzenia, przekonania, wartości na podstawie doświadczenia swojego oraz swojej rodziny. Taka analiza pozwoli jej lepiej opiekować się pacjentami.

Rozwój wiedzy o kulturze: pielęgniarka powinna nauczyć się tak dużo, jak to możliwe, o systemie wiary i praktyk osób ze swojej społeczności i społeczności, którą opiekuje się placówka medyczna, w której pracuje. Powinna obserwować i wprowadzać w życie swoje spostrzeżenia. Rozmawiać ostrożnie na te tematy z pacjentami. Pamiętać, że jeśli jej motywacją będzie troska o pacjenta, szacunek do niego, większość pacjentów będzie miała pozytywne nastawienie. W przypadku gdy kierować będzie się ciekawością, może spotkać się z negatywnym odbiorem.

Uwzględnianie praktyk kulturowych w ochronie zdrowia: pielęgniarka powinna zaimplementować elementy kultury pacjenta do jego leczenia i pielęgnowania, jeśli tylko jest to możliwe bez szkody dla niego oraz procesu leczenia i pielęgnowania. Ignorowanie lub negacja kultury pacjenta może prowadzić z jego strony nawet do odmowy leczenia czy pielęgnacji. Powinna modyfikować pielęgnowanie tak, aby jego częścią stały się praktyki ważne dla pacjenta, bronić praw pacjenta przed naciskami z innych kultur, przestrzegać kulturowych preferencji żywieniowych pacjenta. W szpitalach powinna być możliwość korekty diet/posiłków, aby sprostać oczekiwaniom pacjenta w tym zakresie. 
Szacunek dla mających korzenie w kulturze podziału ról w rodzinie: pielęgniarka powinna dowiedzieć się, kto podejmuje najważniejsze decyzje w rodzinie pacjenta. Czasem będzie to mąż lub inny mężczyzna, czasem ktoś starszy, czasem babcia, matka. Zignorowanie tej osoby w trakcie opieki pielęgniarskiej może prowadzić do konfliktu z rodziną lub z samym pacjentem.

Unikanie zmuszania pacjenta do zmiany: pielęgniarka powinna pamiętać, że praktyki lecznicze to duża część kultury pacjenta i ich zmiana może mieć znaczny wpływ na niego. Powinna zapewnić pacjentowi wsparcie i wyjaśnienie, jeśli zajdzie konieczność zmiany leczenia, pielęgnowania. Nie powinna zmuszać pacjenta, aby był częścią leczenia, pielęgnowania, które są niezgodne z jego wartościami. Jeśli pacjent zostaje zmuszany do takiego leczenia czy pielęgnowania, jest bardzo prawdopodobne, że poczucie winy i niepokój z tego powodu negatywnie wpłyną na jego samopoczucie

Szukanie wsparcia kulturowego: pielęgniarka powinna szukać wsparcia u szanowanego członka rodziny, ludowego uzdrowiciela, członka wspólnoty religijnej, aby pacjent chętniej akceptował plan leczenia i pielęgnowania. Poszanowanie roli ludowego uzdrowiciela może mieć duży pozytywny wpływ na budowanie zaufania pacjenta, promować wspólne zrozumienie, szacunek i współpracę.

Do prostej samooceny kulturowych kompetencji pielęgniarek i ich rozwoju może posłużyć model Campinha-Bacote [42] czy Cross-Cultural Competence Inventory [10]. O innych narzędziach do oceny kompetencji kulturowych mówią Matsumoto i Hwang [47].

Personel medyczny, w tym pielęgniarki, powinien znać kulturowe zasady obsługi pacjentów - cudzoziemców. Dotyczyć powinny one m.in. kwestii związanych z oczekiwaniami pacjentów z odmiennych kultur wobec świadczenia usług medycznych, znajomości terminologii i procesów chorobowych w różnych kulturach, różnic kulturowych w żywieniu, diagnozowaniu, leczeniu, pielęgnowaniu. Personel powinien znać sposoby przekazywania złych wieści w poszczególnych kulturach, daty ważnych świąt w krajach pacjentów i uwzględniać je w planowaniu zabiegów, możliwe sposoby płatności za usługi medyczne, odmienności w systemach podatkowych i ubezpieczeniowych, wymowę imion, nazwisk i kolejność ich używania w poszczególnych kulturach, język lub mieć możliwość skorzystania z pomocy doradcy/pośrednika międzykulturowego [4]. Trudno jest osobom sprawującym opiekę zdrowotną przekazać w artykule charakterystyczne właściwości wszystkich kultur, ale autorki postanowiły zwrócić uwagę na najważniejsze cechy w kilku wybranych kulturach $[4,12,48]$.

Dla przykładu Amerykanie jako pacjenci oczekują od personelu punktualności, podczas witania i pożegna- nia lubią mocny uścisk dłoni i patrzenie prosto w oczy. Oczekują szczegółowego przedstawienia im ich stanu zdrowia, radykalnych zabiegów, ale też przedstawienia metod medycyny alternatywnej, nie tylko opieki stricte medycznej, ale też wsparcia psychicznego. Decyzje w sprawach zdrowia podejmują osobiście, cenią prywatność. Z reguły spokojnie reagują na ból, ale oczekują propozycji podania im leków przeciwbólowych.

Dla pacjentów pochodzących z Bliskiego Wschodu ważne jest praktykowanie religii i przestrzeganie diety bez wieprzowiny. Zalecane jest przeprowadzanie zabiegów przez personel tej samej płci, w przypadku kobiet często w obecności męża lub brata. Niejednokrotnie w nietypowy dla nas sposób komunikują się, np. mówiąc podniesionym głosem, wyrażając w bardzo sugestywny sposób dolegliwości bólowe. Ważne dla nich jest nawiązanie relacji, np. opowiadając coś o sobie. Kontakt bezpośredni wzrokowy z osobą przeciwnej płci, zwłaszcza kobiety z obcym mężczyzną, może być uznany za przejaw seksualnego zainteresowania.

Niemcy i Skandynawowie cenią profesjonalizm, punktualność, perfekcyjność, małomówność (nie mylić z brakiem zainteresowania). Są bezpośredni, nie lubią chwalić, mimo że są zadowoleni z opieki. Bardziej istotne dla nich są ustalenia pisemne niż ustne.

Rosjanie jako pacjenci preferują relacje osobiste. Należy być uważnym, aby ich nie urazić, gdyż przywiązują dużą wagę do tego, co się o nich myśli i mówi. Oczekują od personelu informacji o stanie zdrowia (można je przekazywać rodzinie), profesjonalizmu i współczucia. Mają wysoki próg bólu, wstydzą się do niego przyznać, nie tolerują zażywania dużych ilości leków, mówią donośnie i gestykulują.

Wśród Europejczyków ceniona jest rodzina dwupokoleniowa, dopuszczalne jest, aby starsi członkowie rodziny mieszkali w domach opieki, jeśli nie są w stanie zaopiekować się sobą. Często sami stawiają sobie rozpoznanie choroby, nader często korzystają z leków dostępnych bez recepty, szczególnie witamin, bywają stosunkowo często na okresowych dietach, zwłaszcza odchudzających, korzystają (szczególnie młodzi) z różnych zorganizowanych form aktywności fizycznej.

Dla osób pochodzących z Afryki ważne są więzi w rodzinie oraz bliskie stosunki z osobami, np. należącymi do tego samego kościoła czy organizacji społecznych. Często korzystają w ramach opieki z pomocy zielarzy, spirytystów, uzdrowicieli, osób starszych z rodziny, ludowych i domowych praktyk leczniczych, rzadko z pomocy instytucjonalnej. Dużą wartość dla nich stanowi religia, w codziennym życiu nastawieni są na teraźniejszość.

Azjaci, np. Wietnamczycy, Chińczycy, cenią duże rodziny i sami z takich rodzin pochodzą, dobro rodzi- 
ny jest ważniejsze dla nich niż dobro jednostki, szanują osoby starsze i swoich przodków, przywiązują wagę do dzielenia się dobrami w rodzinie, jeśli któryś z jej członków jest w potrzebie. Choroby i jedzenie dzielą na ciepłe i zimne, uważają, że balans między nimi zapewnia powodzenie (np. na zimną chorobę skuteczne jest ciepłe, pełne ostrych przypraw jedzenie). Korzystają z ziół, diety, terapii ciepłem/zimnem. Wierzą, że istnieją na ciele punkty, przez które biegną ścieżki energii. Jeżeli przepływ energii jest zaburzony, korzystają z akumasażu (technika manipulacji punktów), akupresury (technika ucisku punktów), akupunktury (technika wbijania igły w punkty). Mają silne poczucie samokontroli, duży szacunek do siebie, autorytetów, osób starszych i ciężkiej pracy. Chwalenie siebie i innych w ich mniemaniu nie jest dobrą manierą. Zwracają dużą uwagę na harmonię, unikanie konfliktów i silnych emocji. Niektórzy mogą być niezadowoleni z powodu pobierania krwi do badań, mogą odmówić udziału w badaniach, gdyż uważają krew za ich siłę życiową i nie wierzą w jej regenerację. Nieliczni wierzą, że najlepiej umrzeć z nienaruszonym ciałem, więc nie będą zgadzać się na operacje, za wyjątkiem sytuacji zagrażających życiu. Duża część Azjatów rzadko narzeka na swoje dolegliwości, dlatego ważna jest obserwacja przez pielęgniarkę pacjenta cierpiącego i diagnoza na podstawie znaków niewerbalnych. Niektórzy uważają za uprzejme udzielenie takiej odpowiedzi, jakiej oczekuje pytający (lekarz, pielęgniarka), aby go nie urazić, co może prowadzić do pomyłek, przedawkowania leków, mylenia objawów. Niektórym może być trudno zrozumieć ważność systematycznego zażywania leków, ponieważ wiele metod leczniczych ludowych polega na jednorazowym podaniu ziół, mikstur. Czasami może być potrzebna konsultacja dietetyczna, jeśli pacjent powinien być np. na diecie niskosodowej, gdyż azjatyckie posiłki zawierają dużo soli, np. w sosie sojowym.

\section{Inteligencja kulturowa}

Koncepcja inteligencji kulturowej jest stosunkowo nowym konstruktem, pochodzącym z początków XXI wieku $[49,50]$, będącym odpowiedzią na wyzwania, które niesie globalizacja. Odnosi się do jednostki, podobnie jak inteligencja ogólna, emocjonalna czy społeczna. Jest terminem dobrze opisanym w literaturze anglojęzycznej, znanym w biznesie międzynarodowym, w piśmiennictwie rodzimym natomiast stosowanym rzadko. Jest pojęciem składającym się z czterech komponent: poznawczej, metapoznawczej, motywacyjnej, behawioralnej, i jedenastu subkomponent [5, 51, 52]. W ramach kompetencji poznawczych wyróżniono trzy: przygotowanie planu postępowania przed kontaktem z przedstawicielem innej kultury; uświadomienie sobie własnych uwarunkowań kulturowych i możliwości ich wpływu na komunikowanie międzykulturowe; monitorowanie swojej wiedzy kulturowej podczas relacji z przedstawicielem innej społeczności kulturowej. W ramach kompetencji poznawczych wymieniono dwie: wiedzę kulturową dotyczącą różnic kulturowych i ich wpływu na zachowania, komunikowanie, postrzeganie świata; specyficzną wiedzę kulturową, uwarunkowaną np. zarządzaniem opieką nad pacjentem pochodzącym z odmiennego kręgu kulturowego. W ramach kompetencji motywacyjnych trzy: interes wewnętrzny jednostki - odczuwanie zadowolenia z kontaktu międzykulturowego; interes zewnętrzny odczuwanie satysfakcji ze statusu profesjonalisty, osoby znającej język obcy, umiejącej współpracować np. z pacjentem z innej kultury; poczucie sprawstwa i skuteczności funkcjonowania w odmiennych warunkach kulturowych, które można określić stwierdzeniem „czuję się jak w domu w obu kulturach”. W ramach kompetencji behawioralnych trzy: sposoby wyrażania emocji, myśli, opinii, próśb, poleceń; zachowania werbalne i pozawerbalne (treść słów, gesty, mimika twarzy, pozy, ruchy rąk, odległość do rozmówcy, poruszanie się, dotyk i kontakt wzrokowy lub ich brak, wykorzystanie ciszy) w sposób typowy dla danej kultury czy społeczności. Autorki artykułu uznały, że termin „inteligencja kulturowa” jest wart przeniesienia na grunt pielęgniarstwa i zarządzania zespołem opiekującym się pacjentem pochodzącym z różnych kręgów kulturowych, koniecznym do rozwijania w procesie kształcenia akademickiego studentów pielęgniarstwa, a nie tylko studentów związanych z biznesem międzynarodowym [53]. Jak pisze Starosta [2], inteligencja kulturowa jest specyficzną formą inteligencji, skoncentrowanej na zdolności jednostki do rozumienia, poprawnego wnioskowania, funkcjonowania, zarządzania, radzenia sobie w sytuacjach charakterystycznych dla zróżnicowania kulturowego. Zdaniem Piwowarczyk [53] jest to pewien potencjał ludzki, który da się aktywować w procesie kształcenia uniwersyteckiego. Składnik motywacyjny kładzie nacisk na autentyczne zainteresowanie innymi kulturami i interakcjami z ich reprezentantami. Składowa poznawcza obejmuje znajomość norm, wartości, systemów - np. ekonomicznych, prawnych, ochrony zdrowia, edukacji - funkcjonujących w innych kulturach, zachowań nienaruszających ich norm społecznych. Komponent metapoznawczy odpowiada za świadomość istnienia różnic między kulturami i postrzegania przekonań innych osób przez pryzmat ich kultury, a nie swojej, rodzimej. Składnik behawioralny odnosi się do umiejętności zachowywania zgodnie z normami innych kultur, choćby niektórymi. Inteligencję kulturową można badać z użyciem standaryzowanych narzędzi badawczych [52, 54], jednakże autorki nie dotarły do takich badań prowadzonych na terenie Polski. 


\section{Podsumowanie/wnioski}

Lubowiecki-Vikuk i Gnusowski [4] podkreślają, że posiadanie kompetencji kulturowych pozwala na zmniejszanie potencjalnych negatywnych skutków różnic kulturowych, dotyczących artefaktów, wartości, norm, zachowań (np. związanych z brakiem żywności), do których są przyzwyczajeni cudzoziemcy, innych standardów czystości, odejścia od nawyków, które obowiązywały w rodzimym kraju (godziny wstawania i udawania się na spoczynek nocny, czas posiłków), społecznej alienacji (brak tematów do rozmowy, nieznajomość tematów tabu). Skutkuje unikaniem stereotypowego podejścia do obrazu różnych środowisk, z których pochodzi pacjent i jego rodzina. Redukuje objawy stresu akulturacyjnego. Zdaniem Simpson [5] rozwijanie i doskonalenie inteligencji kulturowej jest procesem rozciągniętym w czasie, trudnym, ale mogącym przynosić satysfakcję, ułatwiającym przełamywanie stereotypów, które utrudniają relacje między przedstawicielami różnych kultur.

Autorki artykułu rekomendują przydatność opisanych zagadnień w pielęgniarstwie w związku z coraz częstszym kontaktem pielęgniarek z pacjentem - cudzoziemcem, w ramach rodzącej się w Polsce mozaiki kultur. Postulują, aby rozwijać kompetencje kulturowe i inteligencję kulturową pielęgniarek w kształceniu, zarówno przed-, jak i podyplomowym. Artykuł stanowi pierwszą część serii artykułów poświęconych sposobom kształcenia kompetencji kulturowych i inteligencji kulturowej wśród pielęgniarek oraz doniesień empirycznych na ten temat.

\section{Piśmiennictwo}

1. Thornson CA. Development and validation of the Crosscultural Competence Inventory. Electronic Theses and Dissertations Paper 1685. University of Central Florida Libraries; 2010, http://library.ucf.edu.

2. Starosta $A$. Inteligencja kulturowa jako niezbędny element zarządzania różnorodnością. Management. 2012; 16(1): 402-412.

3. Nikitorowicz J. Kompetencje do komunikacji międzykulturowej $w$ aspekcie tradycyjnej wielokulturowości regionu i procesów migracyjnych. W: Nikitorowicz J, Sadowski A, Sobiecki M (red.). Pogranicze. Studia Społeczne. Tom XXI. Białystok: Wydawnictwo Uniwersytetu w Białymstoku; 2013. 9-26.

4. Lubowiecki-Vikuk A, Gnusowski M. Rola kompetencji międzykulturowych na rynku turystyki medycznej w Polsce. Hyg Publ Health. 2016; 51(3): 255-261.

5. Simpson D. Znaczenie inteligencji kulturowej w zarządzaniu międzynarodowymi zespołami projektowymi. Horyzonty Polityki. 2017; 8(23): 163-182 (Open Access).

6. Jabłecka B. Migranci i zdrowie - wyzwania wielokulturowości w praktyce medycznej w Polsce. Główne wnioski z badania. Warszawa: Instytut Spraw Publicznych; 2012.

7. Krajewska-Kułak E, Wrońska I, Kędziora-Kornatowska K (red.). Problemy wielokulturowości w medycynie. Warszawa: PZWL; 2010.

8. Majda A, Zalewska-Puchała J, Ogórek-Tęcza B (red.). Pielęgniarstwo transkulturowe. Warszawa: PZWL; 2010.
9. Majda A, Zalewska-Puchała J. Wrażliwość międzykulturowa w opiece pielęgniarskiej. Probl Piel. 2011; 19(2): 253-258.

10. Szkup-Jabłońska M, Schneider-Matyka D, Kubiak J, Grzywacz A, Jurczak A, Augustyniak K, Grochans E. Ocena kompetencji kulturowych pracowników ochrony zdrowia. Fam Med Primary Care Rev. 2013; 15: 394-396.

11. Zdziebło K, Nowak-Starz G, Makieła E, Stępień R, Wiraszka G. Kompetencje międzykulturowe w pielęgniarstwie. Probl Piel. 2014; 22(2): 367-372.

12. Zalewska-Puchała J, Majda A (red.). Różnorodność kulturowa w opiece pielęgniarskiej. Kraków: Wydawnictwo Małopolskiej Okręgowej Izby Pielęgniarek i Położnych im. Hanny Chrzanowskiej; 2014.

13. Krajewska-Kułak E, Guzowski A, Bejda G, Lankau A (red.). Pacjent „Inny” wyzwaniem opieki medycznej. Poznań: Wydawnictwo Naukowe SILVA RERUM; 2016.

14. Majda A, Zalewska-Puchała J. Kulturowo kompetentna opieka pielęgniarska. W: Zarzycka D, Ślusarska B (red.). Podstawy pielęgniarstwa. Założenia koncepcyjno-empiryczne opieki pielęgniarskiej. Tom 1. Warszawa: PZWL; 2017.

15. Chmielecka A (red.). Od migracji do integracji. Vademecum. Warszawa: Helsińska Fundacja Praw Człowieka; 2012.

16. Lubowiecki-Vikuk A, Rab-Przybyłowicz J. Wybrane aspekty funkcjonowania rynku turystyki medycznej w Polsce. Folia Turistica. 2015; 34: 85-107.

17. Zalewska-Puchała J, Majda A. Kompetencje kulturowe w kontaktach z imigrantami pochodzącymi z Wietnamu. Konferencja Naukowo-Szkoleniowa „Człowiek w zdrowiu i chorobie. Promocja zdrowia, leczenie i rehabilitacja”. Tarnów, 17-18.09.2010.

18. Majda A, Zalewska-Puchała J. Wrażliwość międzykulturowa w opiece pielęgniarskiej. Międzynarodowa Konferencja Dydaktyczno-Szkoleniowa „Stulecie pielęgniarstwa w Polsce. Teoria i praktyka pielęgniarstwa XXI wieku". Kraków, 2-3.06.2011.

19. Zalewska-Puchała J, Majda A. Wrażliwość międzykulturowa w opiece położniczej. Międzynarodowy Kongres Położnych „Położna gwarantem sprawnej opieki położniczej i ginekologicznej. Realizacja standardów w opiece położniczo-ginekologicznej". Mierki, 17-19.11.2011.

20. Zalewska-Puchała J, Majda A. Pielęgniarstwo transkulturowe we współczesnym świecie. Konferencja Naukowo-Szkoleniowa „Współczesne pielęgnowanie a dobrostan pacjenta”. Bielsko-Biała, 15.06.2012.

21. Zalewska-Puchała J. Kompetencje międzykulturowe w położnictwie. I Krakowska Konferencja Studentów „Różne kierunki wspólny cel”. Kraków, 20.04.2012.

22. Zalewska-Puchała J, Majda A. Kompetencje międzykulturowe pielęgniarek. Uroczyste Obchody Międzynarodowego Dnia Pielęgniarek i Dnia Położnych. Ostrołęka, 24.04.2013.

23. Zalewska-Puchała J, Majda A. Różnorodność kulturowa w opiece pielęgniarskiej. Uroczyste Obchody Międzynarodowego Dnia Pielęgniarek i Dnia Położnych. Wrocław, 20.05.2015.

24. Majda A, Zalewska-Puchała J, Bodys-Cupak I, Kamińska A. Intercultural education of nurses. International Conference on New Horizons in Education. Barcelona, Spain, June 10-12, 2015.

25. Majda A, Zalewska-Puchała J, Bodys-Cupak I, Kamińska A. Shaping cultural competence of nursing students. W: Lazorova I, Kober L (red.). E-zbornik abstraktov vedeckych a odbornych prac. Osetrovatel'stwo A Porodna Asistencia V Procese Zmien. Vzdelavanie Kompetencje Prax. Vysoke Tatry, Słowacja, 23-24.09.2016. 
26. Zalewska-Puchała J. Niewerbalna komunikacja międzykulturowa. Sympozjum Polskiego Stowarzyszenia Pielęgniarek Urologicznych w Krakowie. Kraków, 8.04.2016.

27. Zalewska-Puchała J, Majda A, Kamińska A, Bodys-Cupak I. Wybrane aspekty komunikowania międzykulturowego. I Małopolska Konferencja dla Pielęgniarek „Wielowymiarowość współczesnego pielęgniarstwa". Niepołomice, 9-10.06.2017.

28. Majda A, Zalewska-Puchała J. Rozwijanie kompetencji kulturowych pielęgniarek. Międzynarodowa Konferencja Naukowa „Jedność w różnorodności. Edukacja międzykulturowa na wspólnym obszarze polsko-słowackiego pogranicza". W ramach mikroprojektu nr INT/EK/PO/3/I/B/0097. Jarosław, 27-29.11.2017.

29. Majda A, Zalewska-Puchała J, Barczyk E. Postawy studentów pielęgniarstwa wobec osób odmiennych kulturowo. Probl Piel. 2013, 21(3): 327-334.

30. Majda A, Zalewska-Puchała J, Barczyk E. Stereotypy i uprzedzenia wobec osób odmiennych kulturowo w świadomości studentów pielęgniarstwa. Probl Piel. 2013, 21(2): 187-194.

31. Szczepanik M. Dobre praktyki. Doświadczenia polskie oraz innych państw przyjmujących obywateli państw trzecich. W: Chmielecka A (red.). Od migracji do integracji. Vademecum. Warszawa: Helsińska Fundacja Praw Człowieka; 2012. 171-208.

32. Jeznach A, Ruszkowska M. Kompetencje do komunikacji międzykulturowej wśród studentów kierunku pielęgniarstwo - rzeczywistość czy iluzja? W: Bajkowski T, Sawicki K, Namiotko U (red.). Diagnostyka i metodyka psychopedagogiczna w warunkach wielokulturowości. Warszawa: Wydawnictwo Akademickie Żak; 2014.

33. Milne A, Cowie J. Promoting culturally competent care: the Erasmus exchange programme. Nurs Stand. 2013; 27(30): 42-46.

34. Neiterman E, Bourgeault IL. Cultural competence of internationally educated nurses: assessing problems and finding solitions. Can J Nurs Res. 2013; 45(4): 88-107.

35. Andrews MM. Theoretical Foundations of Transcultural Nursing. W: Andrews MM, Boyle JS. Transcultural Concepts in Nursing Care. Ed. $3^{\text {rd }}$. Philadelphia: Lippincott; 1999.

36. Andrews MM, Boyle JS. Transcultural concepts in nursing care. Ed. 6th . Philadelphia: Lippincott Williams\&Wilkins; 2012.

37. Giger JN, Davidhizar R. Transcultural nursing: Assessment and intervention. Ed. ${ }^{\text {th }}$. St. Louis: Mosby; 2004.

38. Leininger MM. Culture care diversity and universality: A theory of nursing. New York: John Wiley\&Sons; 1991.

39. Filipowicz G. Zarządzanie kompetencjami zawodowymi. Warszawa: PWE; 2004.

40. Bajkowski T. Uwarunkowania rodzinne kompetencji do komunikacji międzykulturowej współczesnej młodzieży. W: Nikitorowicz J, Sadowski A, Sobiecki M (red.). Pogranicze. Studia Społeczne. Tom XXI. Białystok: Wydawnictwo Uniwersytetu w Białymstoku; 2013. 59-71.

41. Arredondo P, Toporek R, Brown S, Jones J, Locke DC, Sanchez J, Stadler H. Operationalization of the Multicultural Counseling Competencies, www.counseling.org/ Counselors/2006.
42. Campinha-Bacote J. Many Faces: Addressing Diversity in Health Care. The Online Jurnal of Issues in Nursing. 2003; 8(1), http://www.nursingworld.org.

43. Bennett MJ. Towards Ethnorelativism: A Developmental Model of Intercultural Sensivity. W: Paige RM (red.). Education for the Intercultural Experience. Yarmouth, ME: Intercultural Press; 1993. 21-71.

44. Gesteland RN. Różnice kulturowe a zachowania w biznesie. Warszawa: PWN; 2000.

45. Purnell L. The Purnell Model for Cultural Competence. J Transcult Nurs. 2002; 13(3): 193-196.

46. Purnell LD, Paulanka BJ. Guide to culturally competent health care. Ed. 2nd. Philadelphia: F.A. Davis Company; 2009.

47. Matsumoto D, Hwang HC. Assessing cross-cultural competence: A review of availables tests. J Cross-Cult Psychol. 2013; 44(6): 849-873.

48. Taylor C, Lillis C, Lynn P, LeMone P. Fundamentals of Nursing. The Art and Science of Person-Centered Nursing Care. Wolters Kluwer; 2015.

49. Earley PC. Redefining Interactions Across Cultures and Organizations. Moving Forward with Cultural Intelligence. Research in Organizational Behavior. 2002; 24: 271-299.

50. Earley PC, Ang S. Cultural Intelligence. Individual interactions across cultures. Palo Alto: Stanford University Press; 2003.

51. Ang S, Van Dyne L, Koh C. Personality correlates of the four-factor model of cultural intelligence. Group \& Organization Management. 2006; 31(1): 100-123, http://dx.doi. org/10.1177/1059601105275267.

52. Van Dyne L, Ang S, Ng KY, Rockstuhl T, Tan ML, Kok C. SubDimensions of the Four Factor Model of Cultural Intelligence: Expanding the Conceptualization and Measurement. of Cultural Intelligence. Social and Personality Psychology Compass. 2012; 6(4): 295-313.

53. Piwowarczyk AJ. Istota i znaczenie inteligencji kulturowe w kontekście kształcenia uniwersyteckiego. E-mentor. 2016 1(63), http://www.e-mentor.edu.pl/artykul/index/numer/63.

54. Ang S, Van Dyne L, Koh, Ng KY, Templer KJ, Tay C, Chandrasekar NA. Cultural intelligence: Its measurement and effects on cultural judgment an decision making, cultural adaptation and task performance. Management and Organization Review. 2007; 3: 335-371.

Artykuł przyjęty do redakcji: 29.08.2017

Artykuł przyjęty do publikacji: 17.01.2018

Źródło finansowania: Praca nie jest finansowana z żadnego źródła. Konflikt interesów: Autorzy deklarują brak konfliktu interesów.

Adres do korespondencji:
Anna Majda
ul. Piotra Michałowskiego 12
31-126 Kraków
tel. kom.: 506267170
e-mail: anna.majda@uj.edu.pl
Wydział Nauk o Zdrowiu
Uniwersytet Jagielloński - Collegium Medicum

